Check for updates

Cite this: RSC Adv., 2019, 9, 16246

Received 15th December 2018 Accepted 27th April 2019

DOI: 10.1039/c8ra10296a

rsc.li/rsc-advances

\title{
Solid-state emissive O-BODIPY dyes with bimodal emissions across red and near infrared region $\dagger$
}

\author{
H. A. Abdulhadi El-Ali, ${ }^{\text {ab }}$ Jing Jing (D) $^{a}$ and Xiaoling Zhang (D) ${ }^{a}$ \\ Fluorescent compounds with solid-state emission are expected to have broad applications in the \\ development of optoelectronic devices. In this study, we develop O-BODIPY based fluorescent dyes \\ which exhibit strong bimodal solid-state emissions across red and NIR regions. After one pot synthesis, \\ samples are characterized by X-ray diffraction, cyclic voltammetry, UV-vis absorption, and fluorescence \\ spectra. All the experimental data reveal the multiple excitation and efficient emission features in the \\ aggregation states. Furthermore, the two produced probes can be successfully applied for tracking \\ lysosomes in HeLa cells with low cytotoxicity.
}

\section{Introduction}

BODIPY (boron dipyrromethene) is a well established fluorescent dye with strong absorption and high fluorescence efficiency in solution. ${ }^{1}$ It has been used widely as a fluorescent probe for the detection of metal ions, biomolecules, ${ }^{2-4}$ viscosity, polarity and temperature inside living cells, ${ }^{5,6}$ as well as in photodynamic therapy (PDT). ${ }^{7}$ Synthetic procedures have been determined to incorporate a diverse range of functional groups at different positions on a BODIPY platform. Among the widespread range of chemical reactions that can be implemented on BODIPYs, attack on the boron atom opens the gate to the synthesis of abundant fluorophores. Moreover, the modifications that occur reserve the exceptional photophysical properties while refining their stability and solubility either in water or in organic solvents. ${ }^{8-10}$ However, in the solid-state BODIPY undergoes fluorescence quenching, especially in the crystalline form due to the tight close packing which leads to selfquenching because of $\pi-\pi$ stacking. To solve this problem there are many strategic solutions that have focused on substituting the bulk group at the meso, ${ }^{11-14}$ 2,6-positions ${ }^{15,16}$ and 3,5-positions ${ }^{\mathbf{1 7}}$ of BODIPY to enhance the solid-state emission. Also M. Matsui, and Y. Chujo, introduced an effective strategy for enhancing the solid-state quantum yield up to 0.3 through substitution of methoxy, phenoxy and phenyl groups at the boron centre, however, this strategy requires a lot of work..$^{18,19}$ Herein, we introduce two crystal solid-state emissive

${ }^{a}$ Key Laboratory of Cluster Science of Ministry of Education, Beijing Key Laboratory of Photo-electronic/Electro-photonic Conversion Materials, School of Chemistry and Chemical Engineering, Beijing Institute of Technology, Beijing 100081, P. R. China

${ }^{b}$ College of Agriculture, Al-Muthanna University, Samawah, Al-Muthanna Province, Iraq

† Electronic supplementary information (ESI) available. CCDC 1884203 and 1884204. For ESI and crystallographic data in CIF or other electronic format see DOI: $10.1039 / \mathrm{c} 8 \mathrm{ra10296a}$
O-BODIPYs, these dyes are synthesized by coupling 4,4-difluoro1,3,5,7,8-pentamethyl-2,6-diethyl-4-bora-3a,4a-diaza-s-indacene with ethyl 3,4-dihydroxy benzoate and 3,4-dihydroxybenzaldehyde to produce $\mathbf{2 a}$ and $\mathbf{2 b}$, respectively. Since substitution at the boron centre can increase the chemical stability of the synthesized dye, reduce the formation of singlet oxygen,$^{20}$ and decrease the rate of reaction with singlet oxygen, it is worth developing such dyes for important applications in organic light emitting diodes (OLEDs) and solid-state lasers.

\section{Results and discussion}

\subsection{Synthesis and crystal structure determination}

The chemical syntheses of $\mathbf{2 a}$ and $\mathbf{2} \mathbf{b}$ consist of one-step (Scheme 1). ${ }^{23,24}$ We elected 4,4-difluoro-1,3,5,7,8-pentamethyl2,6-diethyl-4-bora-3a,4a-diaza-s-indacene 1 as the scaffold fluorophore for its copiously alkylated core, which helps protect against any side electrophilic reactions that might take place. Moreover 1 has high thermal and chemical stability, and its efficient synthetic route. ${ }^{21,22} 1$ was successfully functionalized in our work by directly perturbing two catechol derivatives bearing ester and aldehyde moieties with moderate yield.

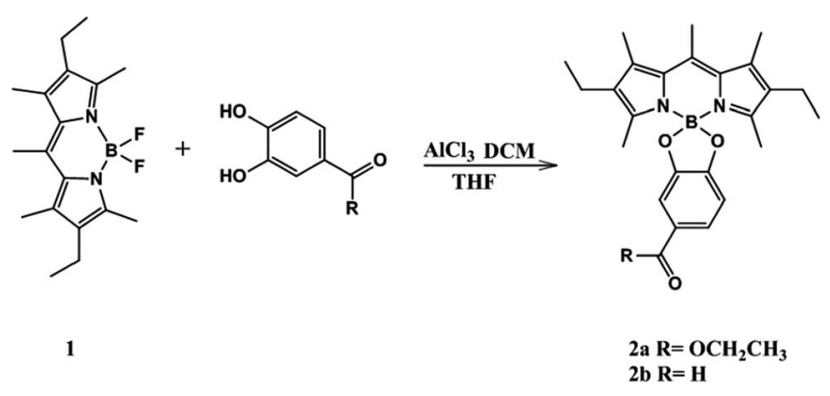

Scheme 1 Synthesis of the probes, $2 a$ and $2 b$. 
Suitable crystals for X-ray diffraction analysis were obtained for $\mathbf{2} \mathbf{a}$ and $\mathbf{2 b}$ from a mixture of ethyl acetate-hexane. The X-ray crystal structure is shown in (Fig. 1). Both compounds form monoclinic crystals, with the centrosymmetric space group, $P 2_{1} /$ $n$ and $P 2_{1} / c$ for $\mathbf{2 a}$ and $\mathbf{2 b}$, respectively. Four molecules are present per unit cell. The boron atom is in a typical tetrahedral geometry. The selected bond distances and angles show that the tetrahedron geometry around the boron atom remains similar after $\mathrm{O}$-functionalization. All the bond lengths and angles were in the range of those for similar O-BODIPYs reported in literature. ${ }^{23,24}$

\subsection{Optical properties in solution}

To validate the possible utility of $\mathbf{2 a}$ and $\mathbf{2 b}$ as fluorescent dyes, we assessed their optical photophysical properties. As shown in Fig. 2 and Table 1 we found that both $\mathbf{2 a}$ and $\mathbf{2 b}$ exhibit similar patterns of absorbance and fluorescence. The maximum absorptions of $\mathbf{2 a}$ and $\mathbf{2 b}$ were $524-528 \mathrm{~nm}$ in different solvents (Fig. S13†) with molar extinction coefficient $50000 \mathrm{~cm}^{-1} \mathrm{M}^{-1}$ and $81566 \mathrm{~cm}^{-1} \mathrm{M}^{-1}$ in ethanol, respectively. The maximum absorption was red shifted $10 \mathrm{~nm}$ compared to that reported for the parent F-BODIPY $\left(\lambda_{\mathrm{ab}} 517 \mathrm{~nm}\right.$ in DCM $) .{ }^{25}$ All the excitation peaks were identical for the absorption peaks in different solvents (Fig. S14 $\dagger$ ). $2 \mathbf{a}$ and $\mathbf{2 b}$ have an emission peaks maxima at 552-566 $\mathrm{nm}$ in various solvents and the fluorescence intensities were higher in organic solvents compared to those in an aqueous solution. O-BODIPY derivatives showed $16 \mathrm{~nm}$ fluorescence red shift compared to that of F-BODIPY $\left(\lambda_{\mathrm{em}} 538 \mathrm{~nm}\right.$ in DCM $).{ }^{25}$ Both compounds undergo red shift and fluorescence quenching in water resulting from aggregation induced quenching. The quantum yield $\left(\Phi_{\mathrm{f}}\right)$ of the probes $\mathbf{2 a}$ and $\mathbf{2 b}$ (0.064-0.23 in ethanol) were far less than the quantum yield of the parent F-BODIPY $\left(\Phi_{\mathrm{f}} 0.83 \text { in DCM }\right)^{25}$ as anticipated because in most cases O-BODIPY undergoes fluorescence quenching and this can be recognized as the fluorescence quenching intramolecular charge transfer (ICT). ${ }^{26}$
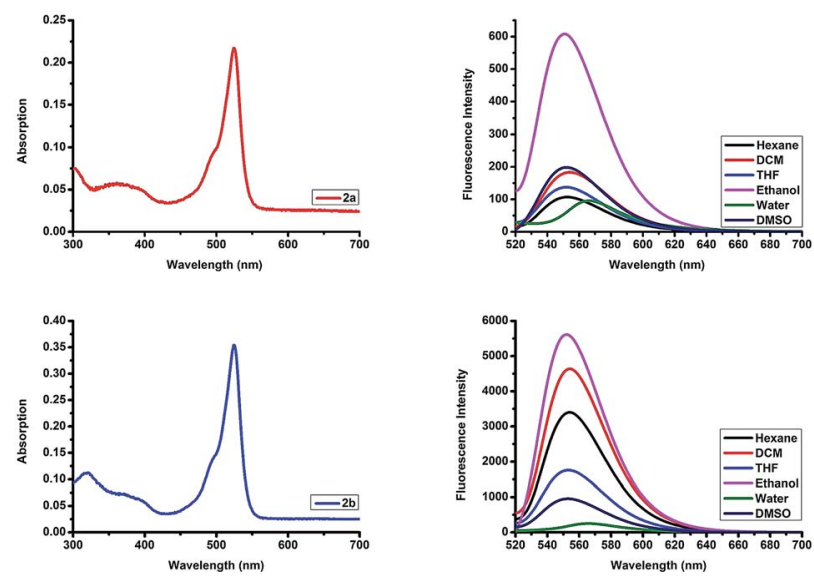

Fig. 2 Top row: absorption spectrum of compound $2 a$ in ethanol, and emission spectra of compound $2 a$ in different solvents. Bottom row: absorption spectrum of compound $2 \mathrm{~b}$ in ethanol, and emission spectra of compound $2 \mathrm{~b}$ in different solvents. $\lambda_{\text {ex }} 510 \mathrm{~nm}$, emission $520-720 \mathrm{~nm}$, concentration $4.34 \mu \mathrm{M}$

\subsection{Photophysical properties in the solid-state}

In order to investigate the solid-state photophysical properties of $\mathbf{2 a}$ and $\mathbf{2} \mathbf{b}$, we measured the solid-state UV-vis absorption spectra and florescence emission, lifetime and quantum yield. Both compounds show continuous absorption of the radiation between $200 \mathrm{~nm}$ and $600 \mathrm{~nm}$ with multiple absorption peaks (Fig. 3). After excitation at $450 \mathrm{~nm}$ the corresponding fluorescence of the dyes occurs at 550-850 $\mathrm{nm}$. Compound 2a shows bimodal emission peaks at red and near IR, and the two peaks are centred at $644 \mathrm{~nm}$ and $765 \mathrm{~nm}$, while $2 \mathbf{b}$ shows bimodal emission peaks in the red region, the two peaks are centred at $615 \mathrm{~nm}$ and $654 \mathrm{~nm}$, while F-BODIPY shows very weak monomodal solid-state emission with $\lambda_{\text {em }} 637$ nm (Fig. S15 $\dagger$ ). Fluorescence lifetime has been measured at $644 \mathrm{~nm}$ after excitation at $375 \mathrm{~nm}$, both compounds showed a very small lifetime value
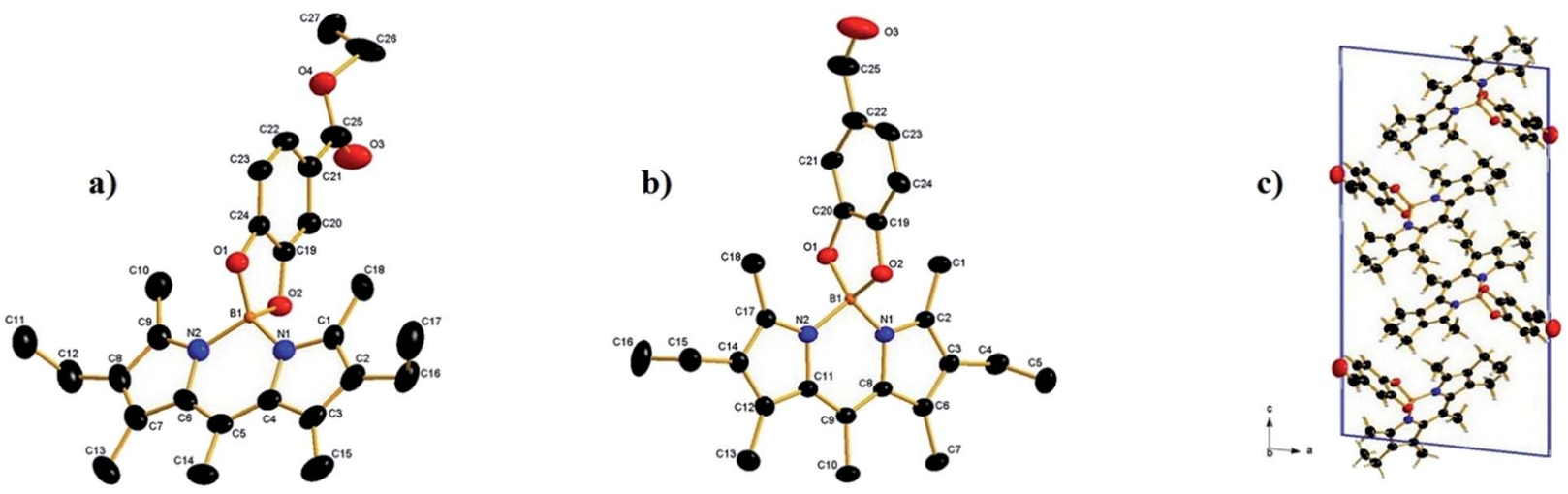

Fig. 1 (a) The crystal structure of compound $2 a$, hydrogen atoms omitted for clarity. Selected bond lengths $(A)$ and angles $\left({ }^{\circ}\right)$ : N1-B1 $=1.533(4)$, $\mathrm{N} 2-\mathrm{B} 1=1.534(4), \mathrm{O} 1-\mathrm{B} 1=1.494(4), \mathrm{O} 2-\mathrm{B} 1=1.480(4), \mathrm{O}(1)-\mathrm{B}(1)-\mathrm{O}(2) 104.6(2) \mathrm{O}(1)-\mathrm{B}(1)-\mathrm{N}(1) 111.2(2), \mathrm{O}(2)-\mathrm{B}(1)-\mathrm{N}(1) 111.4(2), \mathrm{O}(1)-\mathrm{B}(1)-\mathrm{N}(2)$ 112.0(2), $\mathrm{O}(2)-\mathrm{B}(1)-\mathrm{N}(2) 110.8(2), \mathrm{N}(1)-\mathrm{B}(1)-\mathrm{N}(2) 107.0(3),(b)$ crystal structure of compound $2 \mathrm{~b}$, hydrogen atoms omitted for clarity, selected bond lengths $(A \AA)$ and angles $\left({ }^{\circ}\right)$ : N1-B1 =1.540(3), N2-B1 = 1.546(3), O1-B1=1.477 (3), O2-B1=1.486 (3), O(1)-B(1)-O(2) 104.55(17), O(1)-B(1)$\mathrm{N}(1)$ 112.44(18), $\mathrm{O}(2)-\mathrm{B}(1)-\mathrm{N}(1)$ 110.73(19), $\mathrm{O}(1)-\mathrm{B}(1)-\mathrm{N}(2) 111.27(19), \mathrm{O}(2)-\mathrm{B}(1)-\mathrm{N}(2) 111.30(18), \mathrm{N}(1)-\mathrm{B}(1)-\mathrm{N}(2)$ 106.65(17). (c) 2b packing of molecules in a unit cell. 
Table 1 Photophysical properties of $2 \mathrm{a}$ and $2 \mathrm{~b}$ in various solvents

\begin{tabular}{|c|c|c|c|c|c|c|}
\hline \multirow[b]{2}{*}{ Solvent } & \multicolumn{3}{|l|}{$2 a$} & \multicolumn{3}{|l|}{$2 \mathbf{b}$} \\
\hline & $\lambda_{\mathrm{ab}}$ & $\lambda_{\mathrm{em}}$ & $\Phi_{\mathrm{f}}$ & $\lambda_{\mathrm{ab}}$ & $\lambda_{\mathrm{em}}$ & $\Phi_{\mathrm{f}}$ \\
\hline $\mathrm{H}_{2} \mathrm{O}$ & 524 & 566 & 0.05 & 524 & 566 & 0.1 \\
\hline DMSO & 524 & 552 & 0.05 & 524 & 553 & 0.1 \\
\hline Ethanol & 524 & 551 & 0.065 & 524 & 552 & 0.23 \\
\hline THF & 525 & 552 & 0.061 & 526 & 553 & 0.17 \\
\hline DCM & 527 & 554 & 0.060 & 527 & 554 & 0.15 \\
\hline Hexane & 528 & 552 & 0.060 & 528 & 554 & 0.15 \\
\hline
\end{tabular}
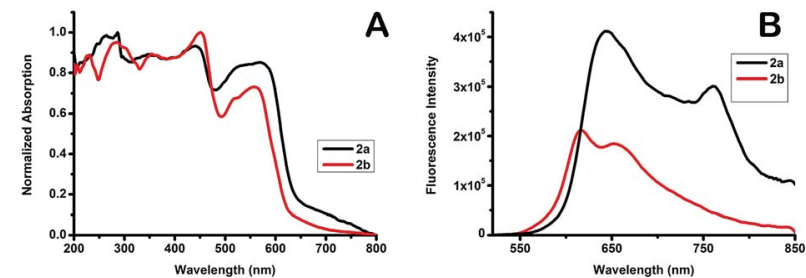

Fig. 3 A: UV-vis absorption spectra of compound $2 a$ and $2 b$ in the solid-state. B: fluorescence spectra of compounds $2 a$ and $2 b$ in the solid-state.

(Table 2), such a short lifetime means the compounds are nonsensitive to oxygen; unfortunately the fluorescence quantum yield of $\mathbf{2} \mathbf{b}$ is quite low while $\mathbf{2 a}$ shows an acceptable value and this can be attributed to the more bulky group substituted at the boron centre of the BODIPY which can quench the $\pi-\pi$ stacking. X-ray spectra show that the crystal density calculated from the unit cell volume of $2 \mathrm{a}\left(1.223 \mathrm{~g} \mathrm{~cm}^{-3}\right)$ is lower than that of $2 \mathbf{b}$ (1.242 $\mathrm{g} \mathrm{cm}^{-3}$ ) which means reduced close packing of the molecules in the unit cell.

\subsection{Electrochemical properties}

Cyclic voltammetry (CV) was employed to examine the electrochemical performance of $\mathbf{2 a}$ and $\mathbf{2 b}$. The oxidation and reduction potentials of the new dyes were assessed by cyclic voltammetry in acetonitrile with tetra- $n$-butylammonium hexafluorophosphate as the supporting electrolyte. Both $\mathbf{2 a}$ and $\mathbf{2 b}$ exhibit a one-electron, reversible oxidation wave with a halfwave potential of $+1.1,+1.04 \mathrm{~V} v s$. SCE, respectively. The corresponding one-electron, reversible reduction wave has a halfwave potential of $-1.20,-1.22 \mathrm{~V}$ vs. SCE. In literature, it has been reported ${ }^{27}$ that the parent F-BODIPY has $E_{\text {ox }}+0.95 \mathrm{~V}$ and $E_{\text {red }}-1.43 \mathrm{~V}$, in comparison, compounds $2 \mathbf{a}$ and $\mathbf{2 b}$, which have two oxygen atoms are harder to oxidize, and half-wave potentials are increased by $150 \mathrm{mV}$ and $90 \mathrm{mV}$, respectively.
Reduction is easier, with the corresponding half-wave potentials being amplified by $230 \mathrm{mV}$ and $210 \mathrm{mV}$, respectively. Both processes remain electrochemically reversible. There is no sign of extra oxidation or reduction within the given electrochemical frame. It is motivating to note that the energy gap between LUMO and HOMO localized on the O-BODIPY dyes declined considerably for the O-BODIPY derivatives comparative to the parent dye 1. Consequently, the energy gap decreased from 2.38 to $2.3 \mathrm{eV}$ for $\mathbf{2 a}$ and $2.26 \mathrm{eV}$ for $2 \mathbf{b}$ on substituting both fluorine atoms with oxygen and this result is in harmonic agreement with the photophysical properties in solution (Fig. 4).

\subsection{Lysosomes imaging}

O-BODIPYs have been used mainly for photophysical purposes like energy harvesting, ${ }^{28}$ to the best of our knowledge there are very few examples of O-BODIPY being used for living cell imaging like monoalkoxy BODIPY. ${ }^{29}$ Before lysosomes tracking, we tried to detect porcine liver esterase with probe $\mathbf{2 a}$ in phosphate buffer; we observed that treatment of probe $2 \mathrm{a}$ with the enzyme at $37^{\circ} \mathrm{C}$ and $\mathrm{pH} 7.4$ leads to $\mathrm{CO}_{2}$ gas bubbling. Analysis of the reaction mixture with HRMS spectrometry showed a peak at $388.1555 \mathrm{~m} / \mathrm{z}$ (Fig. $\mathrm{S} 16 \dagger$ ), which is equivalent to $2 \mathrm{a}$ after ester hydrolysis and the loss of $\mathrm{CO}_{2}$. However, during an enzymatic kinetic study no great variation in fluorescence intensity was observed (Fig. S17 $\dagger$ ). Thus, probe 2 a might be suitable as a $\mathrm{CO}_{2}$ releasing probe as some research is now focusing on $\mathrm{CO}_{2}$ releasing systems for cancer cell treatment. ${ }^{30,31}$

Cytotoxicity was evaluated using standard MTT assays (Fig. S18 $\dagger$ ). Three different concentrations have been used; 10 $\mu \mathrm{M}, 50 \mu \mathrm{M}$, and $100 \mu \mathrm{M}$, indicating that the probes showed low toxicity to the cell cultures at lower concentrations, to moderate toxicity at higher concentrations, under experimental conditions. Staining of HeLa cells with a very low concentration, $1 \mathrm{nM}$, of probe $2 \mathrm{a}$ for 20 min then imaging the cultured cell with confocal fluorescent microscope showed that the probe does
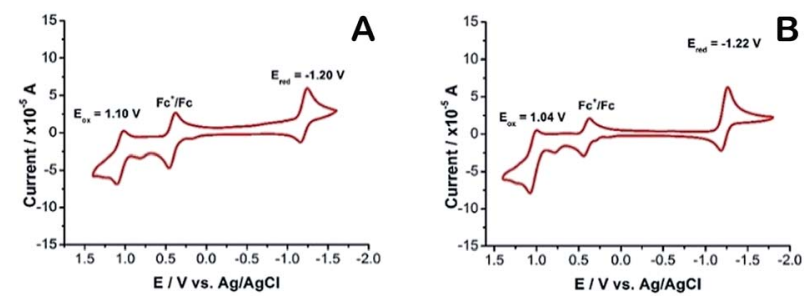

Fig. 4 A: 2b, B: 2a, cyclic voltammetry recorded using a glassy carbon working electrode, supporting electrode $0.1 \mathrm{MnBu}_{4} \mathrm{NPF}_{6}$ in acetonitrile, under argon atmosphere, scan rate at $0.1 \mathrm{~V} \mathrm{~s}^{-1}$, referenced to the internal standard $\mathrm{Fc}^{+} / \mathrm{Fc}$ potential, set at $E_{1 / 2}=0.45 \mathrm{~V}$ vs. SCE.

Table 2 Photophysical properties of $2 \mathrm{a}$ and $2 \mathrm{~b}$ in the solid-state

\begin{tabular}{|c|c|c|c|c|c|c|c|c|}
\hline Entry & $\begin{array}{l}\lambda_{\mathrm{ab}} \\
(\mathrm{nm})\end{array}$ & $\begin{array}{l}\lambda_{\mathrm{em}} \\
(\mathrm{nm})\end{array}$ & $T_{1}(\mathrm{~ns})$ & $T_{2}(\mathrm{~ns})$ & $\Phi_{\mathrm{f}}(\%)$ & $\begin{array}{l}\text { Stokes shift } \\
(\mathrm{nm})\end{array}$ & $K_{\mathrm{f}}\left(\mathrm{s}^{-1}\right)$ & $K_{\mathrm{nr}}\left(\mathrm{s}^{-1}\right)$ \\
\hline $2 \mathbf{a}$ & 440 & 647 & $5.2372(49.47 \%)$ & $9.3088(50.53 \%)$ & 1.4 & 207 & $1.9 \times 10^{6}$ & $1.35 \times 10^{8}$ \\
\hline
\end{tabular}


not distribute inside the cytoplasm, instead it locates at specific organelles, these organelles looked like lysosomes (Fig. S19†). To determine the intracellular location of each probe inside the cells, each probe and the commercial LysoTracker Red were coincubated in HeLa cell lines (Fig. 5). The Pearson's colocalization coefficients were determined as 0.97 and 0.93 (Fig. S20 $\dagger$ ), for probe $\mathbf{2 a}$ and $\mathbf{2 b}$, respectively. By matching our dye structures to commercially available Lysosome trackers like LysoTracker Red DND 9, ${ }^{32}$ we see that they have simple structures and assembly route, thus development of such probes would be low-cost and easy to do large-scale.

\section{Conclusions}

In summary, we have designed and synthesized O-BODIPY dyes for solid-state emission and bioimaging, the synthesized compounds were characterized with ${ }^{1} \mathrm{H}$ NMR, ${ }^{13} \mathrm{C}$ NMR and ${ }^{11} \mathrm{~B}$ NMR. Their structures were further confirmed by single X-ray crystallography, and both compounds $\mathbf{2 a}$ and $\mathbf{2 b}$ display strong bimodal red and NIR solid-state emission in crystalline forms. Moreover, 2a and $\mathbf{2 b}$ dyes have high cell permeability allowing them to be successfully applied for sensing lysosomes in living cells. This finding may open an avenue to engineer new fluorescent probes with improved optical properties based on these two probes as the backbone through smart chemical modifications.

\section{Experimental}

\subsection{Materials and instruments}

All the chemical and biological reagents were obtained from commercial suppliers and used as is without further purification. NMR spectra were recorded on a Bruker Advance III at 400 $\mathrm{MHz}$ for ${ }^{1} \mathrm{H}$ NMR at $100 \mathrm{MHz}$ for ${ }^{13} \mathrm{C}$ NMR and $128 \mathrm{MHz}$ for ${ }^{11} \mathrm{~B}$ NMR with chemical shifts reported as ppm (in $\mathrm{CDCl}_{3}$, TMS as internal standard). HRMS were recorded with Bruker Apex IV FTMS using electrospray ionization. Absorption spectra were recorded on a Purkinje TU-1901 spectrophotometer.

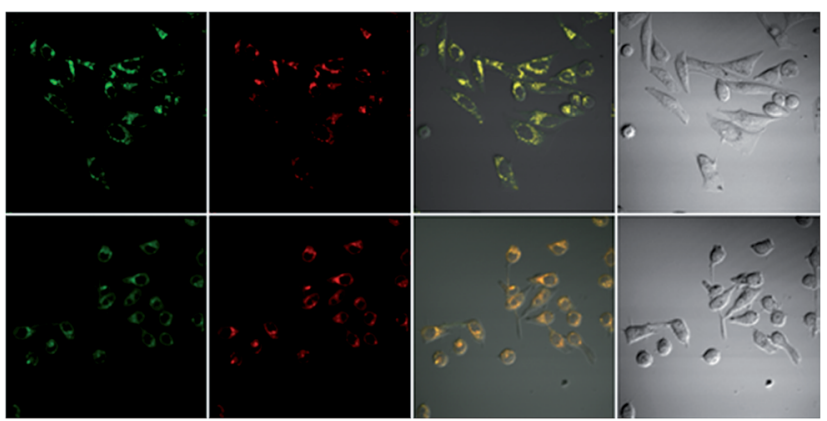

Fig. 5 Top row: colocalization experiment of the probe $2 \mathrm{a} 10 \mu \mathrm{M}$ and LysoTracker Red $1 \mu \mathrm{M}$ in HeLa cell lines. Bottom row: colocalization experiment of the probe $2 \mathrm{~b} 4.5 \mu \mathrm{M}$ and LysoTracker Red $0.5 \mu \mathrm{M}$ in HeLa cell lines. Probes and LysoTracker Red incubated for 20 min then images were taken using confocal microscope. Columns left to right: green channel ex 515 em 560-660 nm. Red channel ex 543 em 600$700 \mathrm{~nm}$. Overlay of the green and red channel. Bright field.
Fluorescence measurements were taken on a Hitachi F-7000 fluorescence spectrometer with a $10 \mathrm{~mm}$ quartz cuvette. $\mathrm{pH}$ measurements were carried out with a $\mathrm{pH}$ acidometer (Mettler Toledo FE-30). Single crystal X-ray diffraction was performed on a D8 Venture Advance diffractometer (Bruker Co.). UV-vis spectra in the solid-state were recorded with a Shimadzu UV3600 spectrophotometer. Solid fluorescence spectra were reported with an FLS 980 fluorescence spectrometer. Confocal images of cells were obtained by confocal laser scanning microscopy (CLSM, FV1000 microscope, Olympus).

\subsection{Synthesis of fluorescent probes}

4.2.1 Synthesis of 4,4-difluoro-1,3,5,7,8-pentamethyl-2,6diethyl-4-bora-3a,4a-diaza-s-indacene. Compound 1 . This compound was synthesized and characterized according to the procedure reported by $\mathrm{M}$. Trudell et $a .^{21}$

4.2.2 General procedure for synthesis of $2 \mathrm{a}$ and $2 \mathrm{~b}$. Compound 1 (0.25 g, $0.786 \mathrm{mmol}, 1$ eq.) was dissolved in anhydrous $\mathrm{CH}_{2} \mathrm{Cl}_{2}(30 \mathrm{~mL})$ and the solution was stirred under nitrogen. $\mathrm{AlCl}_{3}$ (0.526 g, $3.93 \mathrm{mmol}, 5 \mathrm{eq}$.) was added and the solution was stirred until the red color turned violet before the addition of the appropriate catechol derivative (3.93 mmol, 5 eq.) in THF. The mixture was stirred overnight then flushed through deactivated basic alumina $\left(\mathrm{CH}_{2} \mathrm{Cl}_{2}\right.$ as eluent). The crude product was further purified by column chromatography (silica; petroleum ether/ethyl acetate 4/1) to give the product, which crystalized from hexane-ethyl acetate mixture $(4: 1)$ to give the crystal of the pure product.

4.2.2.1 Synthesis of 2a. This compound has been synthesized from ethyl 3,4-dihydroxybenzoate according to the above procedure. Red crystals, yield $50 \%, R_{\mathrm{f}} 0.30$, hexane-ethyl acetate mixture (4: 1), $\operatorname{mp}\left(170{ }^{\circ} \mathrm{C}\right) .{ }^{1} \mathrm{H}$ NMR $\left(400 \mathrm{MHz}, \mathrm{CDCl}_{3}\right) \delta 7.55(\mathrm{~d}$, $J=8.0,1 \mathrm{H}), 7.34(\mathrm{~s}, 1 \mathrm{H}), 6.66(\mathrm{~d}, J=8.0,1 \mathrm{H}), 4.27(\mathrm{q}, J=7.0$, $2 \mathrm{H}), 2.58(\mathrm{~s}, 3 \mathrm{H}), 2.26(\mathrm{~m}, 10 \mathrm{H}), 1.90(\mathrm{~s}, 6 \mathrm{H}), 1.31(\mathrm{t}, J=7.0,3 \mathrm{H})$, $0.91(\mathrm{t}, J=7.3,6 \mathrm{H}) .{ }^{13} \mathrm{C} \mathrm{NMR}\left(101 \mathrm{MHz}, \mathrm{CDCl}_{3}\right) \delta 166.29,155.74$, $152.46,150.78,138.80,136.38,132.17,131.50,122.41,120.84$, 108.58, 106.94, 59.36, 16.23, 16.09, 13.85, 13.60, 13.43, 11.59. ${ }^{11} \mathrm{~B}$ NMR (128 MHz, $\left.\mathrm{CDCl}_{3}\right) \delta$ 7.27. HRMS: $\mathrm{m} / \mathrm{z}$ calcd for $\left[\mathrm{C}_{27} \mathrm{H}_{34} \mathrm{BN}_{2} \mathrm{O}_{4}\right]^{+}: 461.2606[\mathrm{M}+\mathrm{H}]^{+}$; found: 461.2608, $[\mathrm{M}+\mathrm{H}]^{+}$.

4.2.2.2 Synthesis of $\mathbf{2 b}$. This compound has been synthesized from 3,4-dihydroxybenzaldehyde according to the above procedure. Red crystals, yield $65 \%, R_{\mathrm{f}} 0.35$, hexane-ethyl acetate mixture (4:1), $\mathrm{mp}\left(200{ }^{\circ} \mathrm{C}\right) .{ }^{1} \mathrm{H}$ NMR $\left(400 \mathrm{MHz}, \mathrm{CDCl}_{3}\right) \delta 9.73(\mathrm{~s}$, $1 \mathrm{H}), 7.29(\mathrm{~d}, J=7.8,1 \mathrm{H}), 7.22(\mathrm{~s}, 1 \mathrm{H}), 6.76(\mathrm{~d}, J=8,1 \mathrm{H}), 2.58(\mathrm{~s}$, $3 \mathrm{H}), 2.27$ (m, 10H), $1.89(\mathrm{~s}, 6 \mathrm{H}), 0.92(\mathrm{t}, J=7.4,3 \mathrm{H}) .{ }^{13} \mathrm{C} \mathrm{NMR}$ $\left(101 \mathrm{MHz}, \mathrm{CDCl}_{3}\right) \delta 190.37,157.78,152.38,151.79,138.95$, $136.63,132.30,131.54,129.03,126.82,107.32,105.83,16.24$, 16.09, 13.84, 13.62, 11.57. ${ }^{11} \mathrm{~B}$ NMR $\left(128 \mathrm{MHz} \mathrm{CDCl}_{3}\right) \delta 7.32$. HRMS: $m / z$ calcd for $\left[\mathrm{C}_{25} \mathrm{H}_{30} \mathrm{BN}_{2} \mathrm{O}_{3}\right]^{+}: 417.2344[\mathrm{M}+\mathrm{H}]^{+}$; found: 417.2346, $[\mathrm{M}+1]^{+}$.

\subsection{General procedure for measuring fluorescence and} absorbance spectra

Stock solutions of fluorescent probes were prepared in dry DMSO, $1402 \mu \mathrm{M}$ of $2 \mathrm{a}$ and $1808 \mu \mathrm{M}$ of $\mathbf{2 b}$. An appropriate volume of stock solution was transferred into $10 \mathrm{~mL}$ test tube, 
and then diluted with the desired solvent to give $4.34 \mathrm{M}$ of each dye solution. All spectra were obtained in a quartz cuvette (path length $=1 \mathrm{~cm})$.

\subsection{Quantum yield calculation}

Four samples each of rhodamine 6G ( $\Phi=95), \mathbf{2 a}$ and $2 \mathbf{b}$ having different absorbance between $0.01-0.1$ at the excitation wavelength $535 \mathrm{~nm}$, were prepared in ethanol. The fluorescence spectra from 500 to $700 \mathrm{~nm}$ were measured with the prepared samples using an excitation wavelength of $535 \mathrm{~nm}$, the integrated fluorescence intensity was calculated from the spectrum. Plotting the magnitude of the integrated fluorescence intensity against the absorbance of the solution absorbance, we obtained the slope for each series of solution, which has been used for calculating the fluorescence quantum yield by applying the following equation

$$
\Phi=\Phi_{\mathrm{R}}\left(\frac{m}{m_{\mathrm{R}}}\right)\left(\frac{n^{2}}{n_{\mathrm{R}}^{2}}\right)
$$

where $\Phi$ is quantum yield, $m$ is slope, $n$ is the refractive index of the solvent and $\mathrm{R}$ is reference.

\subsection{General procedure for measuring fluorescence and quantum yield in the solid-state}

Solid fluorescence spectra were reported on a FLS 980 fluorescence spectrometer Edinburgh Instruments Ltd., about $30 \mathrm{mg}$ of the pure crystalline solid material was loaded in the sample and the fluorescence was measured after excitation at the appropriate wavelength (Fig. S21†). Quantum yield was measured using the integrated sphere method.

\subsection{Cytotoxicity cells}

HeLa cells were cultured in the DMEM in a $5 \% \mathrm{CO}_{2}$ humidity incubator at $37^{\circ} \mathrm{C}$. Cells were incubated in 96-well plates at 5000 cells per plate. After overnight culture, the medium in each well was replaced with a fresh medium containing $10 \mu \mathrm{M}$ of the required dye. After 24 h, 3-(4,5-dimethylthiazol-2-yl)-2,5-

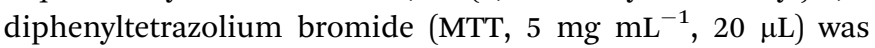
added to each plate and left for $3 \mathrm{~h}$. The medium was then discarded, DMSO $(100 \mu \mathrm{L})$ was added to dissolve the MTT formazan crystals and cultured for another $4 \mathrm{~h}$. The absorbance is directly proportional to viable cell count and was measured by Bio-Rad 680 ELISA at $570 \mathrm{~nm}$ and all the measured results were completed three times under the condition of blank control.

\subsection{Fluorescence imaging and lysosome colocalization in living cells}

HeLa cells were grown on glass-bottom culture dishes using DMEM supplemented with $10 \%$ (v/v) fetal bovine serum (FBS) and $50 \mu \mathrm{g} \mathrm{mL}{ }^{-1}$ penicillin-streptomycin in a humidified $37^{\circ} \mathrm{C}$, $5 \% \mathrm{CO}_{2}$ incubator. Before use, the adherent cells were washed 3 times with FBS-free DMEM. The cells were incubated with LysoTracker Red $1 \mu \mathrm{M}$, and $10 \mu \mathrm{M}$ of $2 \mathrm{a}$ in culture media for $20 \mathrm{~min}$ at $37^{\circ} \mathrm{C}$ (in the case of $2 \mathrm{~b} 4.5 \mu \mathrm{M}$, and LysoTracker Red $0.5 \mu \mathrm{M})$ and were then washed with PBS (pH 7.4) twice.
Fluorescence images were taken with an Olympus IX81 confocal fluorescence microscope.

\section{Conflicts of interest}

There are no conflicts to declare.

\section{Acknowledgements}

This work was supported by the National Nature Science Foundation of China (No. 21575015 and 21505004).

\section{Notes and references}

1 G. Ulrich, R. Ziessel and A. Harriman, Angew. Chem., Int. Ed., 2008, 47, 1184.

2 N. Boens, V. Leen and W. Dehaen, Chem. Soc. Rev., 2012, 41, 1130.

3 Z. Xu, X. Yi, Q. Wu, Y. Zhu, M. Ou and X. Xu, RSC Adv., 2016, 6, 89288.

4 G. Wu, F. Zeng and S. Wu, Anal. Methods, 2013, 5, 5589.

5 A. Vyšniauskas, I. López-Duarte, N. Duchemin, T. T. Vu, Y. Wu, E. M. Budynina, Y. A. Volkova, E. Peña Cabrera, D. E. Ramírez-Ornelas and M. K. Kuimova, Phys. Chem. Chem. Phys., 2017, 19, 25252-25259.

6 S. Arai, S. C. Lee, D. Zhai, M. Suzuki and Y. T. Chang, Sci. Rep., 2014, 4, 6701.

7 P. Majumdar, R. Nomula and J. Zhao, J. Mater. Chem. C, 2014, 2, 5982.

8 R. Ziessel, G. Ulrich and A. Harriman, New J. Chem., 2007, 31, 496.

9 C. Tahtaoui, C. Thomas, F. Rohmer, P. Klotz, G. Duportail, Y. Mély, D. Bonnet and M. Hibert, J. Org. Chem., 2007, 72, 269-272.

10 C. Ray, F. Moreno, A. R. Agarrabeitia, M. J. Ortiz, B. L. Maroto and S. De La Moya, Chem.-Eur. J., 2017, 23, 9383.

11 T. Ozdemir, S. Atilgan, I. Kutuk, L. T. Yildirim, A. Tulek, M. Bayindir and E. U. Akkaya, Org. Lett., 2009, 11, 2105-2107.

12 S. Choi, J. Bouffard and Y. Kim, Chem. Sci., 2014, 5, 751.

13 C. L. Liu, Y. Chen, D. P. Shelar, C. Li, G. Cheng and W. F. Fu, J. Mater. Chem. C, 2014, 2, 5471.

14 Y. Ooyama, Y. Hagiwara, Y. Oda, H. Fukuoka and J. Ohshita, RSC Adv., 2014, 4, 1163.

15 H. Lu, Q. Wang, L. Gai, Z. Li, Y. Deng, X. Xiao, G. Lai and Z. Shen, Chem.-Eur. J., 2012, 18, 7852.

16 D. Tian, F. Qi, H. Ma, X. Wang, Y. Pan, R. Chen, Z. Shen, Z. Liu, L. Huang and W. Huang, Nat. Commun., 2018, 9, 2688.

17 T. T. Vu, M. Dvorko, E. Y. Schmidt, J. F. Audibert, P. Retailleau, B. A. Trofimov, R. B. Pansu, G. Clavier and R. Méallet-Renault, J. Phys. Chem. C, 2013, 117, 5373.

18 Y. Kubota, J. Uehara, K. Funabiki, M. Ebihara and M. Matsui, Tetrahedron Lett., 2010, 51, 6195.

19 H. Yamane, K. Tanaka and Y. Chujo, Tetrahedron Lett., 2015, 56, 6786.

20 K. K. Jagtap, N. Shivran, S. Mula, D. B. Naik, S. K. Sarkar, T. Mukherjee, D. K. Maity and A. K. Ray, Chem.-Eur. J., 2013, 19, 702. 
21 T. Chen, J. H. Boyer and M. L. Trudell, Heteroat. Chem., 1997, 8(1), 51.

22 M. H. R. Beh, K. I. B. Douglas, K. T. E. House, A. C. Murphy, J. S. T. Sinclair and A. Thompson, Org. Biomol. Chem., 2016, 14, 11473.

23 P. Doulain, C. Goze, E. Bodio, P. Richard and A. Richard, Chem. Commun., 2016, 52, 4474.

24 V. J. Richards, A. L. Gower, J. E. H. B. Smith, E. S. Davies, A. G. Slater, W. Lewis, A. J. Blake, N. R. Champness and D. L. Kays, Chem. Commun., 2012, 48, 1751.

25 A. Loudet and K. Burgess, Chem. Rev., 2007, 107, 4891.

26 L. Gartzia-Rivero, E. M. Sánchez-Carnerero, J. Jiménez, J. Bañuelos, F. Moreno, B. L. Maroto, I. López-Arbeloa and S. De La Moya, Dalton Trans., 2017, 46, 11830.
27 C. Goze, G. Ulrich, L. J. Mallon, B. D. Allen, A. Harriman and R. Ziessel, J. Am. Chem. Soc., 2006, 128, 10231.

28 V. Bandi, H. B. Gobeze and F. D’Souza, Chem.-Eur. J., 2015, 21, 11483.

29 A. M. Courtis, S. A. Santos, Y. Guan, J. A. Hendricks, B. Ghosh, D. M. Szantai-Kis, S. A. Reis, J. V. Shah and R. Mazitschek, Bioconjugate Chem., 2014, 25, 1043.

30 K. Zhang, H. Xu, H. Chen, X. Jia, S. Zheng, X. Cai, J. Mou, Y. Zheng and J. Shi, Theranostics, 2015, 5(11), 1291.

31 K. H. Min, H. S. Min, H. J. Lee, D. J. Park, J. Y. Yhee, K. Kim, I. C. Kwon, S. Y. Jeong, O. F. Silvestre, X. Chen, Y. Hwang, E. Kim and S. C. Lee, ACS Nano, 2015, 9(1), 134.

32 T. Kowada, H. Maeda and K. Kikuchi, Chem. Soc. Rev., 2015, 44, 4953. 